\title{
Cultivation of Chlorella vulgaris in Membrane-Treated Industrial Distillery Wastewater: Growth and Wastewater Treatment
}

\author{
Feng $\mathrm{Li}^{\dagger}$, David Kwame Amenorfenyo ${ }^{\dagger}$, Yulei Zhang, Ning Zhang, Changling Li and \\ Xianghu Huang *
}

College of Fisheries, Guangdong Ocean University, Zhanjiang, China

\section{OPEN ACCESS}

Edited by:

Shihai Deng,

X'an Jiaotong University, China

Reviewed by:

Binghan Xie,

Harbin Institute of Technology, Weihai,

China

Xu Zhou,

Harbin Institute of Technology,

Shenzhen, China

Pengfei Cheng,

Ningbo University, China

Vineet Kumar,

Guru Ghasidas Vishwavidyalaya, India

*Correspondence:

Xianghu Huang

huangxh@gdou.edu.cn

${ }^{\dagger}$ These authors have contributed equally to this work and share first

authorship

Specialty section:

This article was submitted to Water and Wastewater Management,

a section of the journal

Frontiers in Environmental Science

Received: 04 September 2021 Accepted: 08 October 2021

Published: 21 October 2021

Citation:

$L i F$, Amenorfenyo DK, Zhang $Y$, Zhang N, Li C and Huang $X$ (2021)

Cultivation of Chlorella vulgaris in Membrane-Treated Industrial Distillery

Wastewater: Growth and

Wastewater Treatment.

Front. Environ. Sci. 9:770633.

doi: 10.3389/fenvs.2021.770633
The alcohol industry discharges large quantities of wastewater, which is hazardous and has a considerable pollution potential. Cultivating microalgae in wastewater is an alternative way of overcoming the current high cost of microalgae cultivation and an environmentally friendly treatment method for industrial effluents. The study analyzed the growth and biochemical composition of Chlorella vulgaris cultivated in membrane-treated distillery wastewater (MTDW) and nutrients removal efficiency. The results showed biomass productivity of $0.04 \mathrm{~g} \mathrm{~L}^{-1} \mathrm{~d}^{-1}$ for MTDW with the contents of content of protein, carbohydrate, and lipid at $49.6 \pm 1.4 \%, 26.1 \pm 0.6 \%$, and $10.4 \pm 1.8 \%$, respectively. The removal efficiencies of TN, TP, and COD were 80,94 , and $72.24 \%$ in MTDW, respectively. In addition, removal efficiencies of $100,85.37$, and $42.86 \%$ for $\mathrm{Ca}^{2+}$, $\mathrm{Mg}^{2+}$, and $\mathrm{Mo}^{2-}$ were achieved, respectively. The study added to our growing knowledge on the cultivation of Chlorella with wastewater, suggesting that it was feasible to cultivate Chlorella with MTDW and represented an economical and environmentally friendly strategy for microalgae biomass production and reuse of wastewater resources.

Keywords: wastewater treatment, microalgae, Chlorella, distiller wastewater, biomass production

\section{INTRODUCTION}

Industrial wastewater is one of the main sources of pollution of the water environment, and its production has a serious negative impact on the ecosystem and human life. Therefore, the fight against wastewater has become a major issue in terms of health, environment, and economy (AbdelRaouf et al., 2012). The quality and quantity of industrial wastewater vary according to the type of industry. The metal processing industry emits chromium, nickel, zinc, cadmium, lead, iron, and titanium compounds. The printing plant releases inks and dyes (Hanchang, 2009). Wastewater from paper mills contains chloride organics and dioxins, as well as suspended solids and organic wastes (Lindholm-Lehto et al., 2015). The petrochemical industry discharges a large number of phenols and mineral oil (Éverton et al., 2018). The content of suspended solids and organic matter in wastewater from food processing plants is very high (Qasim and Mane, 2013). In contrast, distilleries produce large amounts of acidic, stubborn, and colored wastewater with high organic content (Sanjay and Jamaluddin, 2018), which may lead to the destruction of the aquatic environment causing eutrophication, affecting human health and recreational activities (Sanjay and Jamaluddin, 2018; Stutter et al., 2018; Thoré et al., 2021). The alcohol industry discharges up to 0.3 billion $\mathrm{m}^{3}$ of highconcentration wastewater each year in China (Guo et al., 2006), which has become the second largest 
source of organic pollution. Cassava alcohol wastewater is widely produced in cassava-based bioethanol industries (Quan et al., 2014). In general, about 12 tons of wastewater would be generated to produce 1 ton of cassava ethanol (Lin et al., 2016). Industrial wastewater with high organic and acidic substances many contain as high as $40,000 \sim 130,000 \mathrm{mg} \mathrm{L}^{-1}$ chemical oxygen demand (COD) concentration (Gang et al., 2008).

The source of industrial wastewater comes with different characteristics. Hence, the treatment of industrial wastewater should be specifically designed for specific wastewater. Recently, several technologies such as photocatalysis (AlMamun et al., 2019), electrodialysis (Deng et al., 2020; Liu et al., 2020), iron-oxides-doped granular activated carbon catalyst (Deng et al., 2021), and $\mathrm{Fe} / \mathrm{C}$ galvanic cells strengthened A2O process (Fe/C-A2O) (Peng et al., 2020) have been developed with significant effects for industrial wastewater treatment. Presently, distilleries use a multi-stage strategy in wastewater treatment, including pretreatment, secondary treatment, and tertiary treatment. Pretreatment reduces temperature of the wastewater as well as removes suspended solids of large particles in the wastewater (Yang and Wyman, 2007), while an anaerobic wastewater treatment system removed most of the organic matter in the wastewater (Sanjay and Jamaluddin, 2018). Finally, most of the N and P in the wastewater is removed through advanced treatment such as anaerobic and aerobic processes and membrane bioreactor (MBR) (Noor et al., 2013). However, the wastewater after membrane treatment still contains some amount of organic matter, nutrients, and other substances, which may be harmful to the environment. Conventional treatment methods are extensively used, they are however characterized by excessive use of chemicals, high operational and maintenance cost. These methods also generate huge amounts of sludge, thereby making conventional treatment methods environmentally and economically unfavorable (Amenorfenyo et al., 2020).

The microalgae-based wastewater treatment is an environmentally friendly wastewater treatment method, which is often used to treat secondary or tertiary wastewater and is considered one of the promising technologies for wastewater treatment. As a kind of eukaryotic green microalgae with strong photosynthesis ability, Chlorella is considered as one of the easily cultivated microalgae that contains high-quality protein, carotenoids, vitamins, and minerals, it has long been proposed as a healthy food substitute for humans and animals (Liu et al., 2013; Liu et al., 2014; Znad et al., 2018). The use of Chlorella for wastewater treatment and nutrient recovery reduces cost of wastewater treatment, and production of useful biomass (Sánchez-Zurano et al., 2021). In recent years, cultivation of microalgae especially Chlorella vulgaris in wastewater have attracted more and more attention. According to previous studies, Chlorella could remove organic contaminants, and heavy metals from as urban wastewater (Tercero et al., 2014), domestic wastewater (Aziz and Ng, 1992), textile wastewater (Chu et al., 2009), and piggery wastewater (Ji et al., 2012). However, little is known about cultivation of Chlorella in membrane-treated distillery wastewater (MTDW) for nutrient recovery and biomass production, and its feasibility.
In this study, we performed the biomass production of Chlorella coupled with the treatment of MTDW, which seeks to explore the nutrient removal efficiency, biomass production and productivity, and biochemical content of C. vulgaris grown in MTDW. The work sought to give useful information that will lead to the understanding of the cost-effective method of wastewater treatment and microalgae biomass production.

\section{MATERIALS AND METHODS \\ Collection and Pre-Inoculation of Microalgae}

Freshwater algae C. vulgaris was acquired from the laboratory of Ecology of Water Area and Aquaculture Environment of Fisheries College, Guangdong Ocean University, South China. The vegetative cells were grown photoautotrophically at $2000 \mathrm{~lx}$ (white light). The 7-day-old algal cells were collected and inoculated into $2 \mathrm{~L}$ Erlenmeyer flasks filled with $1 \mathrm{~L}$ of BG11 medium at an initial optical density of $0.2\left(\mathrm{OD}_{680}\right)$ in FDFF illuminated incubator $2000 \mathrm{~lx}$ (white light) and $25^{\circ} \mathrm{C}$ for 9 days.

\section{Wastewater Collection and Analysis}

The wastewater used in this study, MTDW was collected from SDIC Guangdong Bio-Energy Co., Ltd., Zhanjiang, South China. The wastewater sample was collected in a $5 \mathrm{~L}$ plastic container that was thoroughly pre-washed with the wastewater from the company. To reduce the decomposition of a substrate, MTDW sample was stored at $4^{\circ} \mathrm{C}$ before the wastewater characteristics analysis. Then wastewater was pretreated by means of filtration using a glass microfiber filter (934-AH, Whatman, United States) to remove turbidity and large particles. The filtered sample was autoclaved at $121^{\circ} \mathrm{C}$ for $30 \mathrm{~min}$ to eliminate bacteria and other algal growth inhibitors.

\section{Determination of Dry Weight and Chlorophyll a}

Microalgae biomass concentration were measured every $72 \mathrm{~h}$. Dry weight (DW) was determined by filtering a $10 \mathrm{ml}$ samples of the algal suspension through pre-weighed $\left(\mathrm{m}_{1}\right)$ filters $(47 \mathrm{~mm}$, $1.2 \mu \mathrm{m}$, Whatman). Then drying the filters $\left(105^{\circ} \mathrm{C}\right.$, overnight $)$ to a constant weight and weighing with microbalance $\left(\mathrm{m}_{2}\right)$. The DW $\left(\mathrm{g} \mathrm{L}^{-1}\right)$ was calculated with Eq. 1.

$$
D W=\left(m_{2}-m_{1}\right) \times 10^{3} / 10 .
$$

Biomass productivity ( $\mathrm{g} \mathrm{L}^{-1}$ day $^{-1}$ ) was calculated with Eq. 2 .

$$
\text { Biomass productivity }=\left(D W_{i}-D W_{0}\right) /\left(t_{i}-t_{0}\right),
$$

where $\mathrm{DW}_{\mathrm{i}}$ and $\mathrm{DW}_{0}$ represent the dry biomass $\left(\mathrm{g} \mathrm{L}^{-1}\right)$ at time $\mathrm{t}_{\mathrm{i}}$ and $\mathrm{t}_{0}$ (day).

The pigment contents of the microalgae thus chlorophyll $a$ was analyzed after extraction in 95\% ethanol (w/v). Briefly, $5 \mathrm{ml}$ of the suspensions were filtered and freeze-dried at $-20^{\circ} \mathrm{C}$ for $12 \mathrm{~h}$; the dried biomass was suspended in ethanol for $4 \mathrm{~h}$ in dark. 
The suspensions were later centrifuged at 5,000 rpm for $10 \mathrm{~min}$ and the pigment contents of the supernatant were spectrophotometrically measured at 665 and $649 \mathrm{~nm}$. The Eq. 3 was used to calculate the pigment contents (Hartmut and Alan, 1983).

$$
\text { Chlorophyll } a=\left(13.95 \times A_{665}\right)-\left(6.88 \times A_{649}\right) .
$$

\section{Carbohydrate, Protein and Lipid Quantification}

Protein extractions were determined according to the modified method described in Barbarino and Lourenço (2005) and Ge et al. (2018). As follows: weigh $30 \mathrm{mg}$ powder of Chlorella, and then add $8 \mathrm{ml}$ of distillery water. After soaking for $12 \mathrm{~h}$, centrifuge at $15,000 \mathrm{rpm}\left(4^{\circ} \mathrm{C}\right)$ for $20 \mathrm{~min}$ to collect the supernatant. Then use $2.0 \mathrm{ml} 0.1 \mathrm{~N}$ (or $2 \mathrm{M}$ ) $\mathrm{NaOH}$ to re-extract the concentrated pellets. After centrifugation at $15,000 \mathrm{rpm}\left(21^{\circ} \mathrm{C}\right)$ for $20 \mathrm{~min}$, the supernatant was collected and mixed with the previous supernatant. $10 \mathrm{ml}$ of the extract was taken to determine protein concentration with the aid of Bio-Rad DC protein assay (Cat. 500-0111, Bio-Rad Laboratories, Hercules, United States). Anthrone colorimetric approach was used to assess carbohydrate and protein content of the supernatants using a Hach model DR 2800 spectrophotometer, glucose, and serum albumin were used as the standard for carbohydrate and protein.

Ge and Champagne (2016) methods were used to assess lipid content. Briefly, the microalgal suspension was harvested via centrifugation $\left(4^{\circ} \mathrm{C}, 5000 \mathrm{rpm}, 10 \mathrm{~min}\right)$, the bio-mass was washed twice with distillery water, and then oven-dried overnight at $60^{\circ} \mathrm{C}$. A $0.1 \mathrm{~g}$ dry biomass of Chlorella was immersed in $3 \mathrm{ml}$ of distillery water and vortexed at $3,000 \mathrm{rpm}$ for $30 \mathrm{~s}$, then placed in a water bath at $90^{\circ} \mathrm{C}$ for $20 \mathrm{~min}$. Methanol/chloroform (extraction solution) of a proportion of $1: 2 \mathrm{v} / \mathrm{v}$ was added after it attained room temperature. The lipids of sample were extracted overnight at room temperature after which, $1 \mathrm{ml}$ of distillery water was added. The organic phase was collected by centrifugation $\left(20^{\circ} \mathrm{C}, 10 \mathrm{~min}\right)$ and transferred into a pre-weighted dish. The chloroform was evaporated at $50^{\circ} \mathrm{C}$, and then the extracted lipids were subjected to gravimetric analysis.

\section{Nutrients Concentration and Removal Efficiency}

All samples were filtered through filter paper $(0.22 \mu \mathrm{m}$, Whatman) and analyzed for nutrients, TN, TP, and COD. Macro and Micronutrients were tested by Qingdao Sci-tech Innovation Quality Testing Co., Ltd. (China). Total Nitrogen (TN), Total phosphorus (TP), and COD were determined every 3 days starting from the day of inoculation. Persulfate digestion method and acid-persulfate digestion method were used for analyzing $\mathrm{TN}$ and $\mathrm{TP}$, respectively. COD concentration was measured with a multi-functional water quality analyzer (LIANHUA, 5B-3B, China).

Nutrient removal efficiency (\%) is calculated by the Eq. 4.

$$
\text { Nutrient removal efficiency }=\frac{\left(C_{0}-C_{1}\right)}{C_{0}} \times 100 \%,
$$

where $\mathrm{C}_{0}$ is the nutrient concentration of the influent and $\mathrm{C}_{1}$ is the nutrient concentration of the effluent.

\section{FAMEs Test and GC Analysis}

A $0.1 \mathrm{~g}$ wet sample of Chlorella was hydrolyzed and methylated with $2 \mathrm{ml}$ of $100 \%$ acetyl chloride in $20 \mathrm{ml}$ of methanol solution at $90^{\circ} \mathrm{C}$ (Ge et al., 2018). Then, filter the sample with filter paper (90 mm, Whatman) by washing it with $10 \mathrm{ml}$ of methanol. Next, use a rotary evaporator to evaporate the methanol, and then add $10 \mathrm{ml}$ of hexane and vortex the sample for $5 \mathrm{~min}$. Use a glass pipette (Fisherbrand ${ }^{\mathrm{TM}}$ Pasteur) to remove the hexane layer and evaporate the hexane, and then analyze the recovered FAME by gas chromatography (GC). Helium was used as a carrier gas. The temperature of the injector and detector is $260^{\circ} \mathrm{C}$. The FAME peaks in the samples were identified by comparing their retention times with those of the standards (Supelco TM 37 component FAME mix, Sigma-Aldrich).

\section{RESULTS}

\section{Microalgae Growth}

C. vulgaris was cultivated in MTDW and BG11 (control) under $30^{\circ} \mathrm{C}, 4,000 \mathrm{~lx}, 40 \%$ Vinoculation/Vmedia growth condition for 15 days to assess biomass and biomass productivity. The growth curve of $C$. vulgaris was shown in Figure 1A. The algal biomass in MTDW and control are $0.65 \mathrm{~g} \mathrm{~L}^{-1}$ and $0.26 \mathrm{~g} \mathrm{~L}^{-1}$ with biomass productivity of $0.04 \mathrm{~g} \mathrm{~L}^{-1} \mathrm{~d}^{-1}$ (MTDW) and $0.02 \mathrm{~g} \mathrm{~L}^{-1} \mathrm{~d}^{-1}$ (control) respectively, after 15 days. This result was totally higher than the results obtained by Tan et al. (2018). The study showed maximum Chl- $a$ (see Figure 1B) content in both the MTDW and the control with $6.48 \pm 0.67 \mathrm{mg} \mathrm{L}^{-1}$ and $1.80 \pm 0.65 \mathrm{mg} \mathrm{L}^{-1}$ on day 14 and day 8 respectively. However, both media showed a decreasing trend in Chl- $a$, with $5.73 \pm 0.94 \mathrm{mg} \mathrm{L}^{-1}$ and $0.76 \pm 0.16 \mathrm{mg} \mathrm{L}^{-1}$ at the end of the cultivation period. Both treatments showed totally different growth patterns. The MTDW experienced a lag phase between day 1 and 2, and the exponential growth phase was experienced in day 3 and lasted for 14 days. The stationary phase set in toward the end of the cultivation period as the nutrient concentration diminished. The control showed steady growth throughout the cultivation period. The lag phase lasted for a day whiles exponential growth begun on the third day and lasted up to day 14 .

\section{Biochemical Composition of C. vulgaris Cultivated in MTDW and BG11 Media}

Table 1 depicts the biochemical composition of C. vulgaris biomass cultivated in MTDW and control (BG11) at the end of the treatment. As the results showed, MTDW demonstrated 2-fold higher protein content than the control. The MTDW recorded $49.6 \pm 1.4 \%$ protein content compared to $22.4 \pm 2.3 \%$ of the control medium. And $26.1 \pm 0.6 \%$ and $29.9 \pm 1.1 \%$, and $10.4 \pm 1.8 \%$ and $16.2 \pm 0.4 \%$ of carbohydrate and lipids for MTDW and the control respectively. Compared with the control, the reason for the lower 

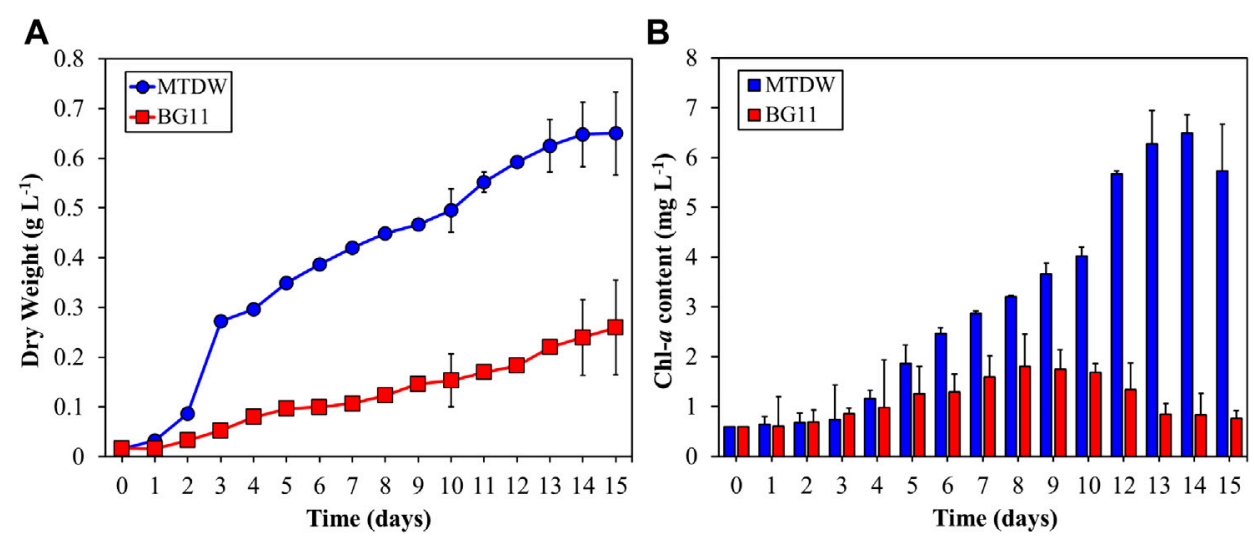

FIGURE 1 | The dry weight (A) and Chl-a content (B) of C. vulgaris in the MTDW group and BG11 group.

TABLE 1 | Biochemical compositions of C. vulgaris cultivated in MTDW and BG11.

\begin{tabular}{lcc}
\hline Composition (\%) & MTDW & Control \\
\hline Protein & $49.6 \pm 1.4$ & $22.4 \pm 2.3$ \\
Carbohydrate & $26.1 \pm 0.6$ & $29.9 \pm 1.1$ \\
Lipid & $10.4 \pm 1.8$ & $16.2 \pm 0.4$ \\
\hline
\end{tabular}

TABLE 2 | Amino acids compositions and contents ( $\mathrm{g} / 100 \mathrm{~g}$ dry biomass) of $C$. vulgaris cultivated in MTDW and BG11.

\begin{tabular}{lcc}
\hline Amino acids & MTDW & BG11 \\
\hline Aspartate & 3.30 & 2.535 \\
Threonine & 1.15 & 0.75 \\
Serine & 1.55 & 0.85 \\
Glutamate & 6.90 & 4.67 \\
Glycine & 3.16 & 2.31 \\
Alanine & 4.16 & 3.350 \\
Valine & 2.89 & 2.30 \\
Isoleucine & 2.12 & 1.40 \\
Leucine & 4.25 & 3.48 \\
Tyrosine & 1.29 & 0.50 \\
Phenylalanine & 2.14 & 1.35 \\
Lysine & 4.46 & 3.345 \\
Histidine & 1.04 & 0.61 \\
Arginine & 5.92 & 3.900 \\
Proline & 2.49 & 1.21 \\
\hline
\end{tabular}

carbohydrate and lipid content in MTDW may be related to the light intensity. This is in agreement with a similar result obtained by Qiu et al. (2019). It is however clear that MTDW can promote protein production in C. vulgaris than BG11 medium. This result was slightly higher than that of Miao et al. (2016). It is documented that higher nitrogen content induces algae growth that could lead to accumulation of amino acid (Martínez et al., 2000). C. vulgaris showed higher biomass growth in MTDW than BG11 which translated into higher protein production.

The amino acid content and composition were analyzed in MTDW and BG11 at the end of the cultivation. As shown in
TABLE 3 | Fatty acid compositions and contents ( $\mathrm{g} / 100 \mathrm{~g}$ dry biomass) of $C$. vulgaris cultivated in MTDW and BG11.

\begin{tabular}{lcc}
\hline Fatty acid & MTDW & BG 11 \\
\hline Myristic Acid (14:0) & 0.11 & 0.14 \\
Pentadecanoic Acid (15:0) & 0.001 & 0.001 \\
Palmitic Acid (16:0) & 0.139 & 0.312 \\
Palmitoleic Acid (16:1) & 0.012 & 0.03 \\
Margaric Acid (17:0) & 0.001 & 0.031 \\
Oleic Acid (18:1) & 0.43 & 0.80 \\
Stearic Acid (18:0) & 0.016 & 0.013 \\
Linoleic Acid (18:2, $\omega$-6) & 0.137 & 0.169 \\
Arachidonic Acid (20:0) & 0.044 & 0.036 \\
$\gamma$-Linolenic Acid (18:2) & 0.003 & 0.003 \\
$\alpha$-Linolenic Acid (18:3) & 0.249 & 0.218 \\
Behenic Acid (22:0) & 0.004 & 0.004 \\
Erucic Acid & 0.068 & 0.078 \\
11,14,17-Eicosatrienoic Acid (20:5 $\omega$-3) & 0.043 & 0.053 \\
Arachidonic Acid & 0.002 & 0.002 \\
13-16-Docosadienoic Acid (22:6, $\omega$-3) & 0.003 & 0.003 \\
Lignoceric Acid & 0.004 & 0.004 \\
15-Tetracosenoic Acid & 0.002 & 0.002
\end{tabular}

Table 2, all tested amino acids in the MTDW group were higher than those in the control group.

GC analysis of fatty acid composition C. vulgaris in both MTDW and the control are shown in Table 3. The contents of Myristic Acid, Palmitic Acid, Margaric Acid, Oleic Acid, Linoleic Acid, Erucic Acid, and 11,14,17-Eicosatrienoic Acid in the MTDW group were lower than those in the control group, and the contents of Palmitoleic Acid, Stearic Acid, Arachidonic Acid, and a-Linolenic Acid were higher than those in the control group. Pentadecanoic Acid, $\gamma$-Linolenic Acid, Behenic Acid, Arachidonic Acid, 13-16-Docosadienoic Acid, Lignoceric Acid, and 15Tetracosenoic Acid were similar in both MTDW and the control.

\section{MTDW Treatment Using C. vulgaris}

\section{TN, TP, and COD Removal}

The concentration of TN, TP, and COD were presented in Figure 2. Nitrogen, is the main component of algal proteins and enzymes catalyst, and are responsible for microalgae 

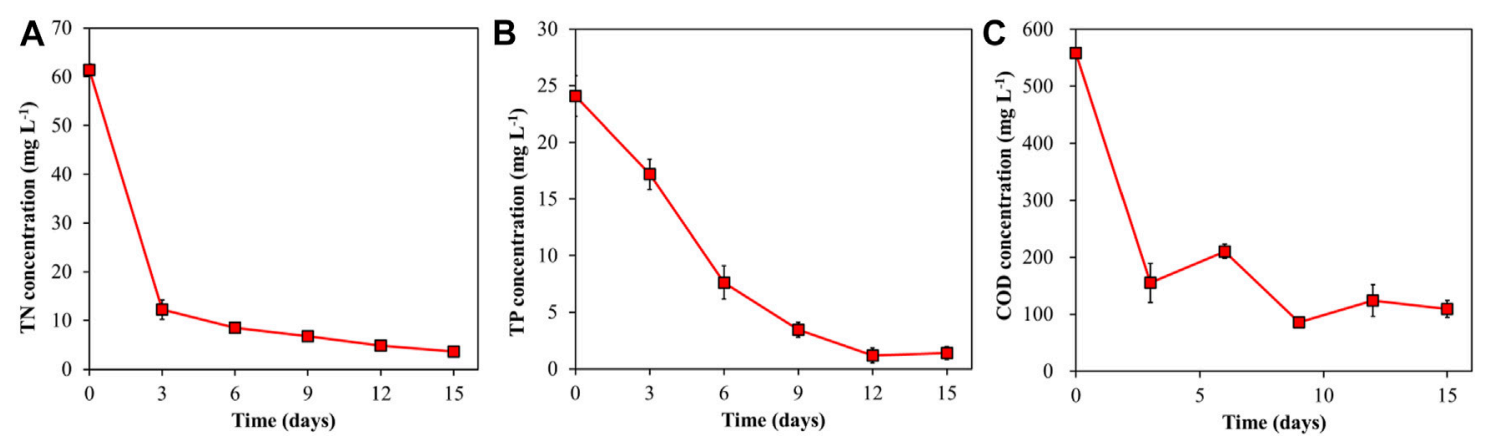

FIGURE 2 | The changes in TN (A), TP (B), and COD (C) concentration of MTDW group.

\begin{tabular}{|c|c|c|c|}
\hline Nutrient & Initial concentration $\left(\mathrm{mg} \mathrm{L}^{-1}\right)$ & Final concentration $\left(\mathrm{mg} \mathrm{L}^{-1}\right)$ & Removal efficiency (\%) \\
\hline \multicolumn{4}{|l|}{ Macro } \\
\hline $\mathrm{K}^{+}$ & 1,020 & 980 & 3.92 \\
\hline $\mathrm{Ca}^{2+}$ & 0.01 & 0.00 & 100 \\
\hline $\mathrm{Mg}^{2+}$ & 18.8 & 2.75 & 85.37 \\
\hline $\mathrm{Zn}^{2+}$ & nd & nd & \\
\hline $\mathrm{Mn}^{2+}$ & nd & nd & \\
\hline $\mathrm{As}^{3+}$ & 0.03 & 0.02 & 33.33 \\
\hline $\mathrm{B}^{-}$ & 0.3 & 0.2 & 33.33 \\
\hline $\mathrm{Mo}^{2-}$ & 0.07 & 0.04 & 42.86 \\
\hline $\mathrm{Pb}^{2+}$ & 0.03 & 0.02 & 33.33 \\
\hline $\mathrm{Cu}^{2+}$ & 0.18 & 0.13 & 27.78 \\
\hline
\end{tabular}

nd: not detected.

growth, photosynthesis and metabolism (Kong et al., 2021). The study showed $80 \%$ TN removal efficiency. However, the highest removal rate was observed on the exponential growth phase. This coincides with a study reported by Iasimone et al. (2018).

Phosphorus is another key element for microalgae growth and other cellular activities (energy transfer and biosynthesis of nucleic acids) (Kong et al., 2021). Affected by the utilization of C. vulgaris, TP concentration decreased steadily within the first 12 days until stable on day 15 . Affected by C. vulgaris, $94 \%$ TP removal efficiency was recorded at the end of cultivation period. Based on the results, phosphorus (TP) removal could directly be affected by $C$. vulgaris growth due to culture conditions. Asian and Kapdan (2006) reported 78\% phosphate removal efficiency for C. vulgaris cultivation at $7.7 \mathrm{mg} \mathrm{L}^{-1}$ initial concentration, less than $30 \%$ removal efficiency at higher concentration, this is clear that cultivation conditions of microalgae could affect phosphorus removal efficiency.

COD concentration (Figure 2C) varied during the period of measurement. There was a slide increase in concentration on day 6 and day 9. Again, the highest COD removal was recorded at the exponential growth phase of C. vulgaris with $72.24 \%$ removal efficiency. It was observed from the results that COD in MTWD was effectively utilized by C. vulgaris.

\section{Macro and Micronutrient Removal}

As shown in Table 4, at the end of the cultivation period, removal efficiency obtained for macronutrients ranged between 3.92 and $100 \%$ compared to $15.56-42.86 \%$ for micronutrients. $\mathrm{Ca}^{2+}$ reduced from the initial concentration of $0.01 \mathrm{mg} \mathrm{L}^{-1}$ to $0.00 \mathrm{mg} \mathrm{L}^{-1}$ in MTDW with a removal efficiency of $100 \%$. The concentration of $\mathrm{Mg}^{2+}$ reduced from $18.8 \mathrm{mg} \mathrm{L}^{-1}$ to $2.75 \mathrm{mg} \mathrm{L}^{-1}$, and the removal efficiency reached $85.37 \%$. The concentration of $\mathrm{Na}^{+}$and $\mathrm{K}^{+}$decreased from $269 \mathrm{mg} \mathrm{L}^{-1}$ to $1,020 \mathrm{mg} \mathrm{L}^{-1}-253 \mathrm{mg} \mathrm{L}^{-1}$ and $980 \mathrm{mg} \mathrm{L}^{-1}$, and the corresponding removal efficiencies were 5.59 and $3.92 \%$, respectively. For micronutrients, $\mathrm{Mo}^{2-}$ had the highest removal efficiency of $42.86 \%$, and the concentration reduced from $0.07 \mathrm{mg} \mathrm{L}^{-1}$ to $0.04 \mathrm{mg} \mathrm{L}^{-1}$. Followed by $\mathrm{As}^{3+}, \mathrm{B}^{-}$, and $\mathrm{Pb}^{2+}$, their concentrations were reduced from $\quad 0.03 \mathrm{mg} \mathrm{L}^{-1}, \quad 0.30 \mathrm{mg} \mathrm{L}^{-1}$, and $0.03 \mathrm{mg} \mathrm{L}^{-1}$ to $0.02 \mathrm{mg} \mathrm{L}^{-1}, 0.20 \mathrm{mg} \mathrm{L}^{-1}$, and $0.02 \mathrm{mg} \mathrm{L}^{-1}$, respectively, and the corresponding removal efficiencies were all $33.3 \%$. The concentration of $\mathrm{Cu}^{2+}$ and $\mathrm{Fe}^{3+}$ in MTDW decreased from the initial $0.18 \mathrm{mg} \mathrm{L}^{-1}$ and $1.80 \mathrm{mg} \mathrm{L}^{-1}$ to $0.13 \mathrm{mg} \mathrm{L}^{-1}$ and $1.52 \mathrm{mg} \mathrm{L}^{-1}$, and the removal efficiency reached 27.78 and $15.56 \%$, which were lower than other micronutrients. In 
addition, $\mathrm{Zn}^{2+}$ and $\mathrm{Mn}^{2+}$ were not detected in this experiment.

\section{DISCUSSION}

Microalgae is a single-cell bioreactor driven by sunlight that converts carbon dioxide into potential proteins, lipids, carbohydrates, and high-value biological compounds, in the presence of a sufficient amount of nitrogen, phosphorous, and some trace elements. By 2024, the overall market potential of algae-based products expected to reach approximately USD 1.143 billion (Mehta et al., 2018). Meanwhile, the viable market potential of microalgae in the phytoremediation of wastewater and biofuels is currently increasing (Mustafa et al., 2021). Wastewater treatment with microalgae has been considered an environmentally sound bioremediation method and applied for more than 60 years (Jing et al., 2007). Many microalgae can grow effectively under wastewater conditions by utilizing the rich inorganic nitrogen and phosphorus in wastewater, such as Desmdesmus sp. (Benítez et al., 2018), Scenedesmus sp. (Han et al., 2020), Acutodesmus dimorphus (Chokshi et al., 2016), C. vulgaris (Lv et al., 2018; Mujtaba et al., 2018), and so on. Due to its rich in protein and other nutrients, bio-safety, and the feasibility of large-scale outdoor cultivation and maintenance, Chlorella has become one of the most in-depth studies of microalgae in biomass production and wastewater treatment (Liu and Chen, 2014). Previous studies have shown that Chlorella can grow and produce biomass in wastewater such as urban wastewater (Tercero et al., 2014), domestic wastewater (Aziz and $\mathrm{Ng}, 1992$ ), textile wastewater (Chu et al., 2009), piggery wastewater (Ji et al., 2012), etc. Our study showed that cultivating Chlorella with MTDW was also a feasible strategy.

Although Chlorella is easily adaptable to different wastewater media, the nutrients in the wastewater significantly affect the growth of microalgae and the production of biomass (Cai et al., 2013). When wastewater is used as a nutrient source for wastewater-based microalgae cultivation, carbon: nitrogen $(\mathrm{C}: \mathrm{N})$ and carbon: phosphorus (C:P) ratios could be considered (Chiu et al., 2015). Lee and Lee (2002) pointed out that Chlorella kessleri culture could successfully remove high concentrations of nitrogen from wastewater supplemented with glucose, indicating that sufficient carbon source supply was beneficial to the utilization of nitrogen and phosphorus. Chui et al. (2015) suggested that the carbon limitation in wastewater could be overcome by adding waste $\mathrm{CO}_{2}$, such as flue gas. In addition, the typical N/P ratio for the optimal conditions for microalgal biomass production is $8: 1$ (Chui et al., 2015). However, the N/P ratio of MTDW is close to $5: 2$, which means that the nitrogen source in the wastewater would be another limiting factor for microalgae growth. According to Chiu et al. (2015), the biomass productivity of Chlorella in different wastewater ranged from $0.029 \mathrm{~g} \mathrm{~L}^{-1} \mathrm{~d}^{-1}$ to $0.64 \mathrm{~g} \mathrm{~L}^{-1} \mathrm{~d}^{-1}$. In contrast, $0.04 \mathrm{~g} \mathrm{~L}^{-1} \mathrm{~d}^{-1}$ biomass productivity of Chlorella cultured in MTDW is not high, indicating that the use of MTDW to cultivate Chlorella to produce biomass still has much room for improvement.

Due to microalgae can use nutrients in wastewater to promote their growth, microalgal are particularly useful for reducing the concentration of inorganic nitrogen and phosphorus of wastewater (Ahluwalia and Goyal, 2007). Previous studies have shown that Chlorella has a very significant removal effect on nitrogen, phosphorus, and COD in different wastewater (Lam et al., 2017; Benítez et al., 2018; Lv et al., 2018; Mujtaba et al., 2018). However, the nutrient concentration of wastewater from different sources is different, which has a direct impact on the removal of nutrients. Kumar et al. (2019) reported that the nitrogen removal efficiency of Chlorella in sewage wastewater $(38 \%)$ was lower than that of kitchen wastewater $(67 \%)$, while the removal efficiency of phosphorus $(88 \%)$ is higher than that of kitchen wastewater (75\%). In this study, the removal rate of TP in MTDW by Chlorella reached 94\%, the removal rate of TN was $80 \%$, and the removal rate of COD exceeded $70 \%$. These results indicate that Chlorella was very effective in MTDW treatment to reduce the organic and inorganic nutrients released into natural water, thereby preventing eutrophication problems.

Many studies have shown that utilizing microalgae could effectively remove metal elements from wastewater (Cabanelas et al., 2013; Cho et al., 2013; Zhu et al., 2013). Some metal ions can be attached to the cell surface through one or more surface complexation, ion exchange, and redox (Sheng et al., 2004; Vinod et al., 2010). Biosorption also involves cell metabolism and other processes, during which metal ions enter the cell through metal transporters, and are finally stored in vacuoles or organelles (Mehta and Gaur, 2005; Flórez-Miranda et al., 2017). Chlorella has been reported to remove many metals from wastewater, including $\mathrm{Al}, \mathrm{Ca}, \mathrm{Cd}$, $\mathrm{Cu}, \mathrm{Fe}, \mathrm{Mg}, \mathrm{Mn}, \mathrm{Ni}, \mathrm{Ur}$, and Zn (Sandau et al., 1996; Lau et al., 1999; Chong et al., 2000; Mehta and Gaur, 2001; Mehta and Gaur, 2005; Wang et al., 2009). Similar to previous studies' conclusions, our study shown that Chlorella could effectively remove $\mathrm{Ca}, \mathrm{Mg}, \mathrm{Mo}, \mathrm{Fe}, \mathrm{As}, \mathrm{B}, \mathrm{Pb}$, and $\mathrm{Cu}$ in distillery wastewater.

Cultivation of microalgae in large quantities is challenged by the high cost of nutrients and freshwater. According to (Kadir et al., 2018), the cultivation of microalgae in wastewater is an alternative way of overcoming the current high cost of microalgae cultivation. Slade and Bauen (2013) estimated more than $50 \%$ reduction in production cost by cultivation microalgae in wastewater as a nutrient, $\mathrm{CO}_{2}$ and freshwater source. The composition of MTDW is stable and could be used for Chlorella cultivation without complicated treatment, which can effectively reduce the cost of Chlorella cultivation. On the other hand, Chlorella can remove nutrients, organic matter, and metals from MTDW. These substances may lead to the destruction of the aquatic environment causing eutrophication, affecting human health and recreational activities (Stutter et al., 2018). In addition, because biomass is rich in protein and fatty acids, C. vulgaris could be cultivated in MTDW as a high-quality protein source in aquaculture. 


\section{CONCLUSION}

The growth and biochemical composition of C. vulgaris cultivated in MTDW and nutrients removal efficiency from the wastewater were analyzed. After cultivated 15 days in MTDW, $0.65 \mathrm{~g} \mathrm{~L}^{-1}$ algal biomass with biomass productivity of $0.04 \mathrm{~g} \mathrm{~L}^{-1} \mathrm{~d}^{-1}$ were obtained. The protein content, carbohydrate, and lipids reached $49.6 \pm 1.4 \%, 26.1 \pm 0.6 \%$, and $10.4 \pm 1.8 \%$, respectively. $94 \%$ of phosphorus and $80 \%$ of nitrogen were removed from MTDW, and the removal efficiency of COD reached $72.24 \%$. In addition, there was the highest removal efficiency of $\mathrm{Ca}^{2+}$ in MTDW with recording a $100 \%$. Followed by $\mathrm{Mg}^{2+}$, an $85.37 \%$ removal efficiency was reached. The removal efficiency of other nutrients $\mathrm{Na}^{+}, \mathrm{K}^{+}, \mathrm{Fe}^{3+}, \mathrm{As}^{3+}, \mathrm{B}^{-}, \mathrm{Mo}^{2-}$, and $\mathrm{Cu}^{2+}$ obtained ranged $3.92-42.86 \%$. This study proved that it was feasible to cultivate Chlorella with MTDW and represented an economical and environmentally friendly Chlorella cultivation strategy. There appears to be a great potential for Chlorella in the

\section{REFERENCES}

Abdel-Raouf, N., Al-Homaidan, A. A., and Ibraheem, I. B. M. (2012). Microalgae and Wastewater Treatment. Saudi J. Biol. Sci. 19 (3), 257-275. doi:10.1016/ j.sjbs.2012.04.005

Ahluwalia, S. S., and Goyal, D. (2007). Microbial and Plant Derived Biomass for Removal of Heavy Metals from Wastewater. Bioresour. Techn. 98, 2243-2257. doi:10.1016/j.biortech.2005.12.006

Al-Mamun, M. R., Kader, S., Islam, M. S., and Khan, M. Z. H. (2019). Photocatalytic Activity Improvement and Application of UV-TiO2 Photocatalysis in Textile Wastewater Treatment: A Review. J. Environ. Chem. Eng. 7 (5), 103248-103437. doi:10.1016/j.jece.2019.103248

Amenorfenyo, D. K., Huang, X., Li, C., Li, F., Zeng, Q., Zhang, N., et al. (2020). A Review of Microalgae and Other Treatment Methods of Distillery Wastewater. Water Environ. J. 34, 988-1002. doi:10.1111/wej.12552

Aslan, S., and Kapdan, I. K. (2006). Batch Kinetics of Nitrogen and Phosphorus Removal from Synthetic Wastewater by Algae. Ecol. Eng. 28 (1), 64-70. doi:10.1016/j.ecoleng.2006.04.003

Aziz, M. A., and Ng, W. J. (1992). Feasibility of Wastewater Treatment Using the Activated-Algae Process. Bioresour. Techn. 40, 205-208. doi:10.1016/09608524(92)90143-L

Barbarino, E., and Lourenço, S. O. (2005). An Evaluation of Methods for Extraction and Quantification of Protein from Marine Macro- and Microalgae. J. Appl. Phycology 17 (5), 447-460. doi:10.1007/s10811-005-1641-4

Benítez, M. B., Champagne, P., Ramos, A., Torres, A. F., and Ochoa-Herrera, V. (2018). Wastewater Treatment for Nutrient Removal with Ecuadorian Native Microalgae. Environ. Techn. 40, 2977-2985. doi:10.1080/09593330.2018.1459874

Cabanelas, I. T. D., Ruiz, J., Arbib, Z., Chinalia, F. A., Garrido-Pérez, C., Rogalla, F., et al. (2013). Comparing the Use of Different Domestic Wastewaters for Coupling Microalgal Production and Nutrient Removal. Bioresour. Techn. 131, 429-436. doi:10.1016/j.biortech.2012.12.152

Cai, T., Park, S. Y., and Li, Y. (2013). Nutrient Recovery from Wastewater Streams by Microalgae: Status and Prospects. Renew. Sust. Energ. Rev. 19, 1364-0321. doi:10.1016/j.rser.2012.11.030

Chiu, S., Kao, C., Chen, T., Chang, Y., Kuo, C., and Lin, C. (2015). Cultivation of Microalgal Chlorella for Biomass and Lipid Production Using Wastewater as Nutrient Resource. Bioresour. Techn. 184, 179-189. doi:10.1016/j.biortech.2014.11.080

Cho, S., Lee, N., Park, S., Yu, J., Luong, T. T., Oh, Y. K., et al. (2013). Microalgae Cultivation for Bioenergy Production Using Wastewaters from A Municipal WWTP as Nutritional Sources. Bioresour. Techn. 131, 515-520. doi:10.1016/j.biortech.2012.12.176

Chokshi, K., Pancha, I., Ghosh, A., and Mishra, S. (2016). Microalgal Biomass Generation by Phycoremediation of Dairy Industry Wastewater: An Integrated area of tertiary distillery wastewater treatment. The feasibility of applying it to full-scale requires further research in culture strategy to maximize biomass production and improve the removal efficiency of nutrients in wastewater.

\section{DATA AVAILABILITY STATEMENT}

The original contributions presented in the study are included in the article/Supplementary Material, further inquiries can be directed to the corresponding author.

\section{AUTHOR CONTRIBUTIONS}

FL: Data curation, methodology, writing-original draft, writingreview and editing; DA: Data curation, investigation, writingoriginal draft; YZ: Methodology; NZ: Methodology; CL: Project administration; $\mathrm{XH}$ : Project administration, resources.

Approach towards Sustainable Biofuel Production. Bioresour. Techn. 221, 455-460. doi:10.1016/j.biortech.2016.09.070

Chong, A. M. Y., Wong, Y. S., and Tam, N. F. Y. (2000). Performance of Different Microalgal Species in Removing Nickel and Zinc from Industrial Wastewater. Chemosphere 41, 251-257. doi:10.1016/S0045-6535(99) 00418-X

Chu, W. L., See, Y. C., and Phang, S. M. (2009). Use of Immobilised Chlorella Vulgaris for the Removal of Colour from Textile Dyes. J. Appl. Phycology 21, 641-648. doi:10.1007/s10811-008-9396-3

Deng, S., Jothinathan, L., Cai, Q., Li, R., Wu, M., Ong, S. L., et al. (2021). FeOx@ GAC Catalyzed Microbubble Ozonation Coupled with Biological Process for Industrial Phenolic Wastewater Treatment: Catalytic Performance, Biological Process Screening and Microbial Characteristics. Water Res. 190, 116687-121354. doi:10.1016/j.watres.2020.116687

Deng, S., Peng, S., Xie, B., Yang, X., Sun, S., Yao, H., et al. (2020). Influence Characteristics and Mechanism of Organic Carbon on Denitrification, N2O Emission and $\mathrm{NO} 2-$ Accumulation in the Iron [ $\mathrm{Fe}(0)]$-Oxidizing Supported Autotrophic Denitrification Process. Chem. Eng. J. 393, 124736-128947. doi:10.1016/j.cej.2020.124736

Flórez-Miranda, L., Cañizares-Villanueva, R. O., Melchy-Antonio, O., MartínezJerónimo, F., and Flores-Ortíz, C. M. (2017). Two Stage Heterotrophy/ Photoinduction Culture of Scenedesmus Incrassatulus: Potential for Lutein Production. J. Biotechnol. 262, 67-74. doi:10.1016/j.jbiotec.2017.09.002

Gang, L., Li, X., Qi, Z., and Sun, J. (2008). Status Quo and Development of the Resource Recycling Treatment Technologies of Cassava Ethanol Wastewater. Ind. Water Treat. 4 (08), 1-5. (In Chinese).

Ge, S., and Champagne, P. (2016). Nutrient Removal, Microalgal Biomass Growth, Harvesting and Lipid Yield in Response to Centrate Wastewater Loadings. Water Res. 88, 604-612. doi:10.1016/j.watres.2015.10.054

Ge, S., Qiu, S., Tremblay, D., Viner, K., Champagne, P., and Jessop, P. G. (2018). Centrate Wastewater Treatment with Chlorella Vulgaris: Simultaneous Enhancement of Nutrient Removal, Biomass and Lipid Production. Chem. Eng. J. 342, 310-320. doi:10.1016/j.cej.2018.02.058

Guo, H. C., Chen, B., Yu, X. L., Huang, G. H., Liu, L., and Nie, X. H. (2006). Assessment of Cleaner Production Options for Alcohol Industry of China: A Study in the Shouguang Alcohol Factory. J. Clean. Prod. 14 (1), 94-103. doi:10.1016/j.jclepro.2004.07.006

Han, J., Thomsen, L., Pan, K., Wang, P., Wawilow, T., Osundeko, O., et al. (2020). Treating Wastewater by Indigenous Microalgae Strain in Pilot Platform Located inside a Municipal Wastewater Treatment Plant. Environ. Techn. 41, 3271. doi:10.1080/09593330.2019.1604816

Hanchang, S. H. I. (2009). Industrial Wastewater-Types, Amounts and Effects. Point Sourc. Pollut. Local Effects Their Control. 2, 191-203. 
Hansen, É., Rodrigues, M. A. S., Aragão, M. E., and de Aquim, P. M. (2018). Water and Wastewater Minimization in A Petrochemical Industry through Mathematical Programming. J. Clean. Prod. 172, 1814-1822. doi:10.1016/j.jclepro.2017.12.005

Hartmut, K., and Alan, R. W. (1983). Determinations of Total Carotenoids and Chlorophylls a and B of Leaf Extracts in Different Solvents. Analysis 4, 142-196. doi:10.1042/bst0110591

Iasimone, F., Felice, V. D., Fantasma, F., Iorizzi, M., and Pirozzi, F. (2018). Effect of Light Intensity and Nutrients Supply on Microalgae Cultivated in Urban Wastewater: Biomass Production, Lipids Accumulation and Settleability Characteristics. J. Environ. Manage. 223, 1078-1085. doi:10.1016/j.jenvman.2018.07.024

Ji, M. K., Kim, H. C., Sapireddy, V. R., Yun, H. S., Abou-Shanab, R. A. I., Choi, J., et al. (2012). Simultaneous Nutrient Removal and Lipid Production from Pretreated Piggery Wastewater by Chlorella Vulgaris YSW-04. Appl. Microbiol. Biotechnol. 97, 2701-2710. doi:10.1007/s00253-012-4097-x

Jing, S., Podola, B., and Melkonian, M. (2007). Removal of Nitrogen and Phosphorus from Wastewater Using Microalgae Immobilized on Twin Layers: An Experimental Study. J. Appl. Phycology 19, 417-423. doi:10.1007/ s10811-006-9148-1

Kadir, W. N. A., Lam, M. K., Uemura, Y., Lim, J. W., and Lee, K. T. (2018). Harvesting and Pre-treatment of Microalgae Cultivated in Wastewater for Biodiesel Production: A Review. Energ. Convers. Manag. 171, 1416-1429. doi:10.1016/j.enconman.2018.06.074

Kong, W., Kong, J., Ma, J., Lyu, Hong., Feng, S., Wang, Z., et al. (2021). Chlorella Vulgaris Cultivation in Simulated Wastewater for the Biomass Production, Nutrients Removal and $\mathrm{CO}_{2}$ Fixation Simultaneously. J. Environ. Manage. 284, 112070. doi:10.1016/j.jenvman.2021.112070

Kumar, P. K., Krishna, S. V., Naidu, S. S., Kavita, V., Bhagawan, D., and Himabindu, V. (2019). Biomass Production from Microalgae Chlorella Grown in Sewage, Kitchen Wastewater Using Industrial $\mathrm{CO}_{2}$ Emissions: Comparative Study. Carbon Resour. Convers. 2 (2), 126-133. doi:10.1016/ j.crcon.2019.06.002

Lam, M. K., Yusoff, M. I., Uemura, Y., Lim, J. W., Khoo, C. G., Lee, K. T., et al. (2017). Cultivation of Chlorella Vulgaris Using Nutrients Source from Domestic Wastewater for Biodiesel Production: Growth Condition and Kinetic Studies. Renew. Energ. 103, 197-207. doi:10.1016/j.renene.2016.11.032

Lau, P. S., Lee, H. Y., Tsang, C. C. K., Tam, N. F. Y., and Wong, Y. S. (1999). Effect of Metal Interference, $\mathrm{pH}$ and Temperature on $\mathrm{Cu}$ and $\mathrm{Ni}$ Biosorption by Chlorella Vulgaris and Chlorella Miniata. Environ. Techn. 20, 953-961. doi:10.1080/09593332008616890

Lee, K., and Lee, C. G. (2002). Nitrogen Removal from Wastewaters by Microalgae without Consuming Organic Carbon Sources. J. Microbiol. Biotechnol. 12 (6), 979-985.

Lin, R., Cheng, J., Yang, Z., Ding, L., Zhang, J., Zhou, J., et al. (2016). Enhanced Energy Recovery from Cassava Ethanol Wastewater through Sequential Dark Hydrogen, Photo Hydrogen and Methane Fermentation Combined with Ammonium Removal. Bioresour. Techn. 214, 686-691. doi:10.1016/j.biortech.2016.05.037

Lindholm-Lehto, P. C., Knuutinen, J. S., AhkolaHerve, H. S. J. S. H., and Herve, S. H. (2015). Refractory Organic Pollutants and Toxicity in Pulp and Paper Mill Wastewaters. Environ. Sci. Pollut. Res. 22, 6473-6499. doi:10.1007/s11356-015-4163-x

Liu, J., and Chen, F. (2014). "Biology and Industrial Applications of Chlorella: Advances and Prospects," in Microalgae Biotechnology. Editors C Posten and F Chen (Springer. Part of the Advances in Biochemical Engineering/ Biotechnology book series), 1-35. doi:10.1007/10_2014_286

Liu, J., and Hu, Q. (2013). "Chlorella: Industrial Production of Cell Mass and Chemicals," in Handbook of Microalgal Culture: Applied Phycology and Biotechnology. Editors A Richmond and Q Hu (Wiley), 329-338. doi:10.1002/9781118567166.ch16

Liu, Y., Ke, X., Zhu, H., Chen, R., Chen, X., Zheng, X., et al. (2020). Treatment of Raffinate Generated via Copper Ore Hydrometallurgical Processing Using a Bipolar Membrane Electrodialysis System. Chem. Eng. J. 382, 122956-128947. doi:10.1016/j.cej.2019.122956

Lv, J. P., Liu, Y., Feng, J., Liu, Q., Nan, F. R., and Xie, S. L. (2018). Nutrients Removal from Undiluted Cattle Farm Wastewater by the Two-Stage Process of Microalgae-Based Wastewater Treatment. Bioresour. Techn. 264, 311-318. doi:10.1016/j.biortech.2018.05.085

Martínez, M. E., Sánchez, S., Jimenez, J. M., El Yousfi, F., and Munoz, L. (2000). Nitrogen and Phosphorus Removal from Urban Wastewater by the Microalga Scenedesmus Obliquus. Bioresour. Technol. 73 (3), 263-272. doi:10.1016/S09608524(99)00121-2
Mehta, P., Singh, D., Saxena, R., Rani, R., Gupta, R. P., Puri, S. K., et al. (2018). "'High-Value Coproducts from Algae-An Innovational Way to Deal with Advance Algal Industry", ' in Waste to Wealth. Editors R Singhania, R Agarwal, R Kumar, and R Sukumaran Springer. Part of the Energy, Environment, and Sustainability Book Series, 343-363. doi:10.1007/978-981-10-7431-8_15

Mehta, S. K., and Gaur, J. P. (2001). Removal of Ni and Cu from Single and Binary Metalsolutions by Free and Immobilized Chlorella Vulgaris. Eur. J. Protistology 37, 261-271. doi:10.1078/0932-4739-00813

Mehta, S. K., and Gaur, J. P. (2005). Use of Algae for Removing Heavy Metal Ions from Wastewater: Progress and Prospects. Crit. Rev. Biotechnol. 25, 113-152. doi:10.1080/07388550500248571

Miao, M. S., Yao, X. D., Shu, L., Yan, Y. J., Wang, Z., Li, N., et al. (2016). Mixotrophic Growth and Biochemical Analysis of Chlorella Vulgaris Cultivated with Synthetic Domestic Wastewater. Int. Biodeterioration Biodegradation 113, 120-125. doi:10.1016/j.ibiod.2016.04.005

Mujtaba, G., Rizwan, M., Kim, G., and Lee, K. (2018). Removal of Nutrients and COD through Co-culturing Activated Sludge and Immobilized Chlorella Vulgaris. Chem. Eng. J. 343, 155-162. doi:10.1016/j.cej.2018.03.007

Mustafa, H. M., Hayder, G., and Jagaba, A. H. (2021). Microalgae: A Renewable Source for Wastewater Treatment and Feedstock Supply for Biofuel Generation. Biointerface Res. Appl. Chem. 11, 7431-7444. doi:10.33263/BRIAC111.74317444

Mutamim, N. S. A., Noor, Z. Z., Hassan, M. A. A., and Yuniarto, A. (2013). Membrane Bioreactor: Applications and Limitations in Treating High Strength Industrial Wastewater. Chem. Eng. J. 225, 109-119. doi:10.1016/j.cej.2013.02.131

Peng, S., Deng, S., Li, D., Xie, B., Yang, X., Lai, C., et al. (2020). Iron-Carbon Galvanic Cells Strengthened Anaerobic/Anoxic/Oxic Process (Fe/C-A2o) for High-Nitrogen/Phosphorus and Low-Carbon Sewage Treatment. Sci. Total Environ. 722, 137657-139697. doi:10.1016/j.scitotenv.2020.137657

Qasim, W., and Mane, A. V. (2013). Characterization and Treatment of Selected Food Industrial Effluents by Coagulation and Adsorption Techniques. Water Resour. Industry 4, 1-12. doi:10.1016/j.wri.2013.09.005

Qiu, S., Wang, L., Pascale, C., Gao, G., Chen, Z., Wang, S., et al. (2019). Effects of Crystalline Nanocellulose on Wastewater-Cultivated Microalgal Separation and Biomass Composition. Appl. Energ. 239, 0306-2619. doi:10.1016/j.apenergy.2019.01.212

Quan, X., Tao, K., Mei, Y., and Jiang, X. (2014). Power Generation from Cassava Alcohol Wastewater: Effects of Pretreatment and Anode Aeration. Bioproc. Biosyst Eng 37 (11), 2325-2332. doi:10.1007/s00449-014-1210-9

Sánchez-Zurano, A., Guzmán, J. L., Acién, F. G., and Fernández-Sevilla, J. M. (2021). An Interactive Tool for Simulation of Biological Models into the Wastewater Treatment with Microalgae. Front. Environ. Sci. 9, 298. doi:10.3389/fenvs.2021.721324

Sandau, E., Sandau, P., and Pulz, O. (1996). Heavy Metal Sorption by Microalgae. Acta Biotechnologica 16, 227-235. doi:10.1002/abio.370160402

Sanjay, P., and Janmaluddin (2018). Treatment of Distillery Waste Water: A Review. Int. J. Theor. Appl. Sci. 10 (1), 117-139.

Sheng, P. X., Ting, Y. P., Chen, J. P., and Hong, L. (2004). Sorption of Lead, Copper, Cadmium, Zinc, and Nickel by Marine Algal Biomass: Characterization of Biosorptive Capacity and Investigation of Mechanisms. J. Colloid Interf. Sci. 275, 131-141. doi:10.1016/j.jcis.2004.01.036

Slade, R., and Bauen, A. (2013). Micro-algae Cultivation for Biofuels: Cost, Energy Balance, Environmental Impacts and Future Prospects. Biomass and Bioenergy 53, 29-38. doi:10.1016/j.biombioe.2012.12.019

Stutter, M. I., Graeber, D., Evans, C. D., Wade, A. J., and Withers, P. J. A. (2018). Balancing Macronutrient Stoichiometry to Alleviate Eutrophication. Sci. Total Environ. 634, 439-447. doi:10.1016/j.scitotenv.2018.03.298

Tan, X. B., Zhao, X. C., Zhang, Y. L., Zhou, Y. Y., Yang, L. B., and Zhang, W. W. (2018). Enhanced Lipid and Biomass Production Using Alcohol Wastewater as Carbon Source for Chlorella Pyrenoidosa Cultivation in Anaerobically Digested Starch Wastewater in Outdoors. Bioresour. Technol. 247, 784-793. doi:10.1016/ j.biortech.2017.09.152

Tercero, E. A. R., Sforza, E., Morandini, M., and Bertucco, A. (2014). Cultivation of Chlorella Protothecoides with Urban Wastewater in Continuous Photobioreactor: Biomass Productivity and Nutrient Removal. Appl. Biochem. Biotechnol. 172, 1470-1485. doi:10.1007/s12010-013-0629-9

Thoré, E. S. J., Schoeters, F., De Cuyper, A., Vleugels, R., Noyens, I., Bleyen, P., et al. (2021). Waste Is the New Wealth - Recovering Resources from Poultry Wastewater for Multifunctional Microalgae Feedstock. Front. Environ. Sci. 9, 253. doi:10.3389/fenvs.2021.679917 
Vinod, V. T. P., Sashidhar, R. B., and Sreedhar, B. (2010). Biosorption of Nickel and Total Chromium from Aqueous Solution by Gum Kondagogu (Cochlospermum Gossypium): A Carbohydrate Biopolymer. J. Hazard. Mater. 178, 851-860. doi:10.1016/j.jhazmat.2010.02.016

Wang, L., Min, M., Li, Y. C., Chen, P., Chen, Y. F., Liu, Y. H., et al. (2009). Cultivation of Green Algae Chlorella Sp. In Different Wastewaters from Municipal Wastewater Treatment Plant. Appl. Biochem. Biotechnol. 162, 1174-1186. doi:10.1007/s12010-009-8866-7

Yang, B., and Wyman, C. E. (2008). Pretreatment: The Key to Unlocking Low-Cost Cellulosic Ethanol. Biofuels, Bioprod. Bioref. 2 (1), 26-40. doi:10.1002/bbb.49

Zhu, L., Wang, Z., Takala, J., Hiltunen, E., Qin, L., Xu, Z., et al. (2013). Scale-up Potential of Cultivating Chlorella Zofingiensis in Piggery Wastewater for Biodiesel Production. Bioresour. Techn. 137, 318-325. doi:10.1016/ j.biortech.2013.03.144

Znad, H., Al Ketife, A. M. D., Judd, S., AlMonmani, F., and Vuthaluru, H. B. (2018). Bioremediation and Nutrient Removal from Wastewater by Chlorella Vulgaris. Ecol. Eng. 110, 1-7. doi:10.1016/j.ecoleng.2017.10.008
Conflict of Interest: The authors declare that the research was conducted in the absence of any commercial or financial relationships that could be construed as a potential conflict of interest.

Publisher's Note: All claims expressed in this article are solely those of the authors and do not necessarily represent those of their affiliated organizations, or those of the publisher, the editors and the reviewers. Any product that may be evaluated in this article, or claim that may be made by its manufacturer, is not guaranteed or endorsed by the publisher.

Copyright (C) 2021 Li, Amenorfenyo, Zhang, Zhang, Li and Huang. This is an openaccess article distributed under the terms of the Creative Commons Attribution License (CC BY). The use, distribution or reproduction in other forums is permitted, provided the original author(s) and the copyright owner(s) are credited and that the original publication in this journal is cited, in accordance with accepted academic practice. No use, distribution or reproduction is permitted which does not comply with these terms. 